\title{
Jalostuksen tehostamisen vaikutus maidontuotannon kannattavuuteen
}

\author{
Leena Kärkkäinen ${ }^{1)}$, Matti Ylätalo ${ }^{1)}$ Jarmo Juga $^{2)}$, Risto Kauppinen ${ }^{3)}$, Hilkka Kämäräinen ${ }^{3)}$ \\ ${ }^{1)}$ Helsingin yliopisto, Taloustieteen laitos, 00014 Helsinki etunimi.sukunimi@ helsinki.fi \\ ${ }^{2)}$ Helsingin yliopisto, Maataloustieteiden laitos, 00014 Helsinki etunimi.sukunimi@helsinki.fi \\ ${ }^{3)}$ Savonia ammattikorkeakoulu, PL 72, 74101 Iisalmi etunimi.sukunimi@ savonia.fi
}

\section{Tiivistelmä}

Tutkimuksen tavoitteena on arvioida sukupuolilajitellun siemenen käytön ja genomisen valinnan vaikutusta maidontuotannon kannattavuuteen ja laatia ohjeet eläinaineksen optimaaliseen uudistukseen ja taloudellisesti järkevään liharotusiemenen käyttöön maidontuotantotiloilla. Asiantuntija-arvioiden perusteella liharotusiemennysten määrää lypsykarjatiloilla on mahdollista nostaa huomattavasti nykyisestä 6 prosentista. Valtakunnallisesti pyrkimyksenä on tuottaa enemmän lihaa samoilla resursseilla. Tässä hankkeessa tarkastelu aiotaan tehdä kuitenkin tilatasolla. Tarkoituksena on laatia ohjelma liharotusiemenen käytöstä erilaisille tilakokoluokille. Kokoluokat ovat 30 lehmää, 64 lehmää (yksi lypsyrobotti), 130 lehmää (kaksi lypsyrobottia) ja 500 lehmää (pohjoisen tuen katto). Pyrkimyksenä on selvittää jalostuksellisen edistymisen nopeutta perinteisiä jalostusarvoennusteita tai genomista valintaa käyttäen. Mahdollisesti laadittavien tilamallilaskelmien avulla pyritään löytämään taloudellisesti kannattavin uudistusvaihtoehto ja liharoturisteytyssiemenen käyttöosuudet eri kokoluokissa.

Tämä tutkimus kuuluu MAILI-hankekokonaisuuteen. Kilpailukykyä ja ympäristötehokkuutta pohjoissavolaisille maito- ja lihanautatiloille ja lihantuotantoketjulle eli MAILI -hanke on Pohjois-Savon ELYkeskuksen rahoittama hanke, joka kuuluu Manner-Suomen maaseudun kehittämisohjelmaan 2007-2013. Hankkeen hallinnoija on Savonia ammattikorkeakoulu ja toteuttajina ovat Savonia ammattikorkeakoulun lisäksi Maa- ja elintarviketalouden tutkimuskeskus MTT ja Helsingin yliopisto. Hankkeessa ovat mukana Valio Oy, Atria Oyj, HK Agri Oy, Saarioinen Oy, Snellman Lihanjalostus Oy, ProAgria ja Faba Osk. Hanke toteutetaan vuosina 2011-2013.

MAILI -hankkeen tavoitteena on pyrkiä parantamaan naudanlihantuotannon omavaraisuutta ja tehostaa maitotilojen ja lihanautatilojen sekä maidon- ja lihanjalostusteollisuuden kilpailukykyä ja ympäristötehokkuutta. Lisäksi selvitetään, voidaanko maidontuotantotiloilta saatavien vasikoiden avulla tuottaa enemmän hyvälaatuista naudanlihaa kustannus- ja ympäristötehokkaasti. Pyrkimyksenä on selvittää maitoliharoturisteytysvasikoiden taloudellinen merkitys maidon- ja lihantuottajalle. Tilamallien avulla selvitetään eri toimenpiteiden vaikutus maito- ja lihanautatilojen kannattavuuteen. Hankkeella pyritään edistämään uusien jalostusmenetelmien käyttöönottoa pohjoissavolaisilla tiloilla ja kehitetään jalostusohjelmamallia sekä tuotetaan koulutusmateriaalia ja siirretään tietoa eri kohderyhmille.

Asiasanat: kotieläinjalostus, genominen valinta, maidontuotanto, kannattavuus 


\section{Johdanto}

Tämän tutkimuksen tavoitteena on tarkastella uusien jalostusmenetelmien käytön vaikutusta maitotilan talouteen. Tutkimuksessa halutaan selvittää, missä laajuudessa sukupuolilajitellun sperman ja genomisen valinnan käyttö on perusteltua taloudellisesti maitotilalla.

Tämä tutkimus kuuluu MAILI-hankekokonaisuuteen. Kilpailukykyä ja ympäristötehokkuutta pohjoissavolaisille maito- ja lihanautatiloille ja lihantuotantoketjulle eli MAILI -hanke on Pohjois-Savon ELYkeskuksen rahoittama hanke, joka kuuluu Manner-Suomen maaseudun kehittämisohjelmaan 2007-2013. Hankkeen hallinnoija on Savonia ammattikorkeakoulu ja toteuttajina ovat Savonia ammattikorkeakoulun lisäksi Maa- ja elintarviketalouden tutkimuskeskus MTT ja Helsingin yliopisto. Hankkeessa ovat mukana Valio Oy, Atria Oyj, HK Agri Oy, Saarioinen Oy, Snellman Lihanjalostus Oy, ProAgria ja Faba Osk. Hanke toteutetaan vuosina 2011-2013.

Hankkeen tavoitteena on edistää uusien jalostusmenetelmien käyttöönottoa maitotiloilla. Näitä menetelmiä ovat genominen valinta ja sukupuolilajitellun sperman käyttö. Niiden käytön edistämisellä halutaan nopeuttaa lypsykarjan jalostuksen edistymistä. Samalla halutaan edistää liharotuisten sonnien käyttöä lypsylehmien siemennyksissä, kun riittävä määrä lehmävasikoita uudistukseen saadaan pienemmästä joukosta lehmiä ja hiehoja kuin aiemmin. Lypsykarjatilan lehmävalinta voidaan nyt ottaa tehokkaaseen käyttöön. Jalostusmenetelmiä peilataan tässä tutkimuksessa taloudellisuuteen. Tutkimuksessa halutaan tietoa, onko uusien jalostusmenetelmien käyttöönotolla positiivisia vaikutuksia maitotilan talouteen. Millaisia säästöjä tai lisätuloja se tuo.

Genominen valinta nopeuttaa perinnöllistä edistymistä tehostamalla valintaa. Genominen jalostusarvo saadaan selville jo pienestä vasikasta koska jalostusarvon ennuste perustuu eläimen koko genomin kattaviin DNA-merkkeihin. Aiemmin on täytynyt odottaa omia tuloksia tai sonneilla jälkeläisten tuloksia.

Sen lisäksi, että eläimen perinnöllisestä tasosta saadaan tieto jo vasikkana, genomisen valinnan avulla voidaan saada luotettavampaa tietoa heikon periytymisasteen ominaisuuksista, kuten terveys-, hedelmällisyys- ja kestävyysominaisuuksista.

Genominen valinta lyhentää sukupolviväliä niin sonneilla kuin lehmillä. Sonneilla ei tarvitse odottaa 4,5-5 vuotta jälkeläisarvostelun valmistumista, vaan sonnin perinnöllinen taso tiedetään jo nuorena. Sonninemillä genominen arvostelu lisää arvosteluvarmuutta ja nopeuttaa arvostelun saamista. Lehmänemien valinta genomista arvostelua käyttäen on yksi tämän tutkimuksen tavoitteesta. Kannattaisiko kaikki hiehoiksi jätettävät ensiksi testauttaa ja karsia genomisen arvon perusteella heikoimmat? Onko taloudellisesti kannattavampaa valita genomisen arvon perusteella kuin jättää enemmän lehmävasikoita kasvamaan ja karsia epäonnistuneet yksilöt ensikkona.

Schaeffer $(2006,220)$ on laskenut genomisesta arvostelusta koituvia säästöjä keinosiemennysorganisaatiolle. Kanadassa jälkeläisarvosteltiin aikaisemmin 500 sonnia vuodessa. Kustannussäästöt ovat merkittävät, kun odotusajan sonneista voidaan luopua ja valita suoraan 20 parasta genomitestattua sonnia keinosiemennyskäyttöön. Syntyvillä säästöillä voidaan helposti maksaa genomityypityskustannukset. Genomisen arvostelun etuna on myös se, että sonnit tulevat käyttöön vuoden ikäisenä, jolloin sperman laatu on parempi kuin käytettäessä viisi vuotiaan jälkeläisarvostellun sonnin spermaa. (Schaeffer 2006, 220.)

Sukupuolilajitellun sperman käytöllä saadaan haluttua sukupuolta oleva jälkeläinen. X-spermalla tehdystä siemennyksestä syntyy lehmävasikka $90 \%$ todennäköisyydellä ja Y-spermalla siemennettäessä todennäköisyys sonnivasikan syntymiseksi on $85 \%$. Siemennettäessä hyvät lehmät ja hiehot X-spermalla voidaan lehmävalinnan kynnys asettaa korkeammalle kuin normaalia spermaa käytettäessä, koska uudistukseen tarvittava määrä lehmävasikoita saadaan pienemmästä emien joukosta.

Sörensen, Voergaard, Pedersen, Berg ja Sörensen $(2011,267)$ ovat tutkineet sukupuolilajitellun sperman käytön vaikutusta perinnölliseen edistymiseen. Se oli 2,1 \% nopeampaa vuodessa verrattuna tavallisen spermaa käytettäessä. Sonnien ja sonninemien välinen geneettinen ero väheni $12-14 \%$, kun sukupuolilajiteltua spermaa käytettiin parhaille sonninemille.

Y-sperman käyttö puoltaa paikkansa lypsykarjatiloilla siemennettäessä heikoimpia lehmiä, joista ei haluta jättää jälkeläisiä. Syntyvä vasikka on sonni, joka voidaan myydä välitykseen tai kasvattaa itse teuraaksi. Sonnivasikasta saa korkeamman hinnan välityksessä ja se kasvaa paremmin. Hyötyä koituu sekä lypsykarja- että lihanautatilalle. Y-spermalla siemennettäessä käytetään liharotuista sonnia. Liharoturisteytys sonneista saadaan risteytyslisä välityksessä. Liharotuisen sonnin kasvatus tuo myös naudanlihatuotantotilalle parhaimman tuloksen, koska ne kasvavat korkeaan teuraspainoon, ne sijoittuvat parempiin lihakkuusluokkiin 
kuin lypsyrotuinen teurasnauta ja ne eivät rasvoitu niin helposti kuin lypsyrotuiset (Idström 2011). Huuskonen, Pesonen, Hyrkäs, Kämäräinen ja Kauppinen (2011, 14-15) ovat tutkimuksessaan todenneet, että liharoturisteytysten käyttö lypsyrotuisilla eläimillä lisää jälkeläisen nettokasvua ja teuraspainoa sekä ayrshire- että holsteinristeytyksillä. Samoin lihakkuus paranee. Rasvaisuuteen liharoturisteytysten käytöllä ei näyttäisi olevan korjaavaa vaikutusta.

Huuskonen, Rantakangas, Kokkonen, Kauppinen, Kainulainen, Lindeberg ja Suhonen $(2004,20)$ ovat tehneet tutkimuksen liharotusiemennyksistä lypsykarjatiloilla. Tärkeimmäksi perusteluksi liharotusiemennysten käytölle vastaajat kertovat jalostuksen etenemisen. Korkeatuottoisissa karjoissa tämä jalostuksellinen peruste oli vielä selvempi kuin heikompituottoisissa karjoissa. Yleisin syy liharoturisteytysten käytön vähyyteen on epäily lehmävasikoiden riittävyydestä. Toiseksi yleisin syy oli pelko vaikeista poikimisista liharodulla siemennettäessä. (Huuskonen ym. 2004, 20-21).

\section{Tutkimus}

Tällä tutkimuksella on tarkoitus luoda mallit lypsykarjatilan järkevään uudistukseen. Jo ennen siemennystä mietitään, mistä lehmistä otetaan jälkeläisiä kasvamaan lehmiksi. Mallit luodaan erikokoisille tiloille. Lehmämäärältään nämä olisivat 30, 64, 130 ja 500 lehmää. Jokaiseen tilakokoluokkaan lasketaan tarvittavien uudistuseläinten määrä. Sen pohjalta vertaillaan liharotuisten sonnien käyttöä lypsyrotuisten siemennyksissä, joka tällä hetkellä on $6,5 \%$. Seuraava vaihtoehto on jalostussuunnitelman suositus $15 \%$. Toinen vaihtoehto on uudistustarpeen ylimenevien lehmien siementäminen liharotuisella. Kolmannessa vaihtoehdossa lasketaan samoin kuin edellisessä, mutta nyt käytetään parhaille sukupuolilajiteltua spermaa. (Kuvio 1.) Lypsykarjan uudistukseen tarvittavien eläinten määrää laskettaessa huomioidaan karjan uudistus- \%, käyttöikä ja poikimaväli. Tutkimuksessa halutaan selvittää liharotuvasikan sopiva hinta teurastamon välityksessä. Kuinka paljon korkeampaa hintaa kannattaa maksaa paremmasta kasvukyvystä ja paremmin luokittuvasta ruhosta?

\section{TUTKIM UKSEN VIITEKEHYS}

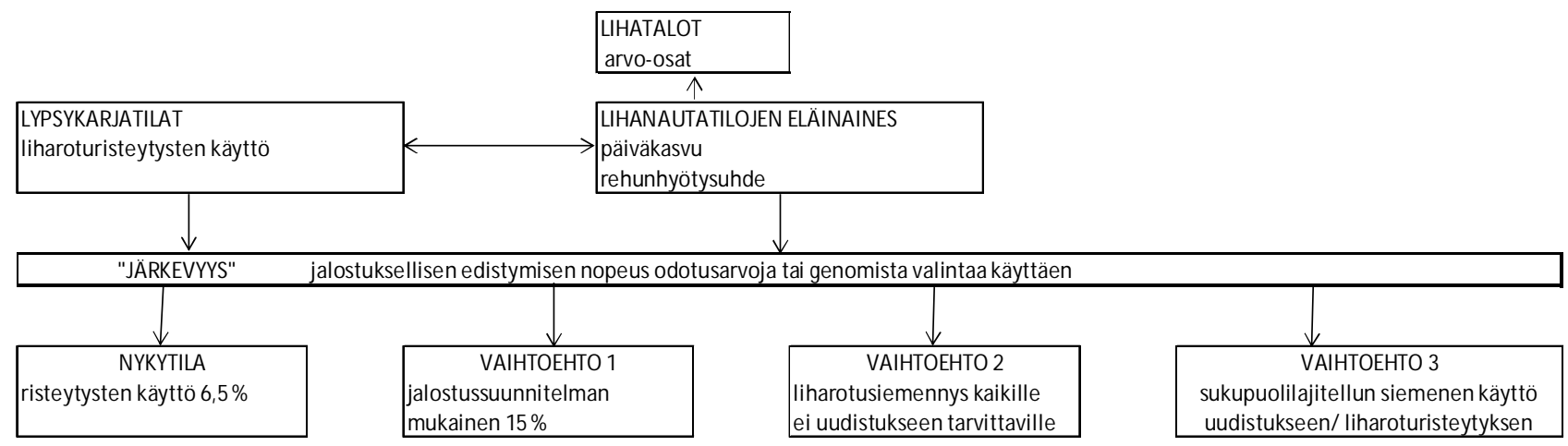

Kuvio 1. Tutkimuksen viitekehys

Genomisen jalostusarvon ennusteen vertaamisessa odotusarvoon täytyy huomioida genominäytteen otosta ja määrityksestä koituvat kustannukset. Tätä verrataan genomisen valinnan talousvaikutuksiin lypsykarjatilalla.

Sukupuolilajitellun sperman käytössä huomioitavia seikkoja ovat lajitellun siemenen korkeampi hinta ja heikompi tiinehdyttämiskyky. Niitä verrataan lajitellun sperman käytöstä saatavaan hyötyyn lehmävalinnan tason nostolla.

Liharotuisten sonnien spermaa on tällä hetkellä Suomessa saatavilla kuutta eri rotua: Aberdeen Angus, Blonde d’Aquitaine, Charolais, Hereford, Limousin ja Simmental. Limousin- ja Simmental-rotuisten sonnien spermaa on tarjolla myös sukupuolilajiteltuna. Joukossa on sekä pieniä, keskikokoisia että isoja liharotuja. Niiden karkearehun ja väkirehun hyväksikäyttökyvyssä on eroja ja niin on kasvussakin. Liharotuisten sonnien käytössä lypsyroturisteytyksissä muuttujina ovat sukupuolilajiteltu tai lajittelematon sperma ja siitä johtuvat hintaerot annoksissa, välitysvasikan hintaero johtuen isärodusta, poikimistyyppierot, eri rotujen pidemmät kantoajat ja vasikoiden elinkyky verrattuna puhtaisiin lypsyrotuisiin. 


\section{Kirjallisuus}

Huuskonen, A., Rantakangas, A., Kokkonen, J., Kauppinen, R., Kainulainen, P., Lindeberg, H. ja Suhonen, P. 2004. Liharotusiemennykset osana lypsylehmien uudistusstrategiaa. MTT:n selvityksiä: 20-21 s.

Huuskonen, A., Pesonen, M., Hyrkäs, M., Kämäräinen, H. ja Kauppinen, R. 2011. Maito-liharoturisteytyksillä tehoa naudanlihantuotantoon. Lihatalous 6/2011 s. 14-15.

Idström, A. 2011. Taloudellisesti optimaalinen naudanruho - teurastamon näkökulmasta. Helsingin Yliopisto Taloustieteen laitos. Pro Gradu-tutkielma.

Schaeffer, L.R. 2006. Strategy for applying genome-wide selection in dairy cattle. Journal of Animal Breeding and Genetics 123: 218-223 s.

Sörensen, M.K., Voergaard, J., Pedersen, L.D., Berg, P. Ja Sörensen, A.C. 2011. Genetic gain in dairy cattle populations is increased using sexed semen in commercial herds. Journal of Animal Breeding and Genetics. Volume 128. Issue 4: 267-275 s. 